\title{
Vulnerable children, alternative care system and placement decision in Nigeria: In who's best interest?
}

\section{Chinwe U. Nnama-Okechukwu, Nkemdilim P. Anazonwu \& Uzoma O.Okoye}

\author{
Department of Social Work, University of Nigeria Nsukka \\ Email:nkemdilim.anazonwu@unn.edu.ng
}

\begin{abstract}
Background: Alternative care system has been found to provide children in need of care and protection with a safe haven pending their unification back to their family of origin. There is however concerns with the process leading to children going into alternative care system.

Data Source and Method: Focus Group Discussion (FGD) was used as the main source of data collection. Purposive and snowball sampling method were used in selecting 64 participants from a rural and urban setting for the study.

Result: Findings revealed that placement decisions are made by extended family members and friends with little or no active participation of the child in need of placement.

Conclusion: Findings suggest the need to have professional social workers. Professional social workers will help in the monitoring and assessment of the suitability of the placement for children in alternative care system.
\end{abstract}

Keywords: Alternative care system, Best interest, Placement decision, South East Nigeria, Vulnerable children

\section{Introduction}

Goal one of the Sustainable Development Goals (SDGs) according to the 2015 United Nations Development Programme (UNDP) report is to end poverty in all its forms everywhere. This is closely followed by goal two which seeks to provide access to quality education and lifelong learning opportunities. This report identified poverty as more than lack of income or resources but includes lack of basic services such as education; lack of participation in decision making, social discrimination and exclusion which negatively affects the emotional development of children through the environment it creates (UNDP, 2015). The fact still remains that half a billion people around the world still live on less than $\$ 1.25$ a day (Green, 20I5).

Poor families still struggle to provide basic needs and send their children to school because they lack the means to do so. To cope with the situation, most families seek alternative care system for their children so to provide them with better opportunities to quality education, basic needs and lifelong learning opportunities in what is consider to be in the best interest of the child (UNICEF, 20I7). Millions of children around the world however still face the reality of being deprived of growth and development in a caring family environment due to poverty (Boothby, Batster, \& Goldman, 2012; Heyman, Sherr\& Kidman, 2012; Malinga\&Ntshwarang, 20II; Tshoose, 2010; World Vulnerable Children, 2010). This deprivation may lead to placement in an alternative care system. Alternative child care system 4215 has been identified as a means of providing care and support for vulnerable children when parents or guardians are unable to fulfill their parental responsibilities (Williamson, \& Greenberg, 2010; United Nation Nations Guidelines on the Alternative Care of Children, 2010).

Globally, there are over 2.7 million children who are in alternative care system due to various factors (UNICEF, 20I7). Several factors such as poverty, family breakdown (parental divorce/separation), parental death or loss of caregiver, health issues, poor or unequal provision of social services, disability, socio-cultural issues, need to attend school, large family size, social security, have been identified by various scholars as factors leading to alternative care system (Asuman, Boakye-Yiadom\&Owoo, 2018; Bledose\&Isiugo Abanihie, 1989; Gaydosh, 2015; Isiugo Abanihie, 1983; Isiugo Abanihie, 1985; Jones, PreslerMarshall, Cooke, \&Akinrimisi, 2012; Lachsnd, LeGramd\&Kobiane , 2016; Lawson, Schaffnit, Hassan, Ngadaya, Ngowi, Mfinanga, James, \&Borgerhoff Mulder, 2017, Okafor \&Amayo, 2006, Tade, 2010). While previous studies revealed that the major reason why children are placed in alternative care system are largely due to poverty (Okafor \&Amayo, 2006, Tade, 2010). More recent study however found that even though poverty is undoubtedly closely linked with major placements into alternative care system in many ways. It is increasingly agreed that poverty in itself is not the major reason for children being placed in alternative care system at

http://aps.journals.ac.az 
least in the formal system (Chaitkin, Gale, Miligan, Flagotherie, O'Kane \&Connely, 20I7). In a study on the 'Orientation for reforming alternative care system in Africa, Asia and Latin America', Chaitkin, et.al (2017) explained that poverty increases vulnerability but does not explain alone recourse to placement in alternative care system.

The use of alternative care system for children in need of care and protection has proven to provide children with a safe haven at least for absorbing the increasing number of vulnerable children (Elegbeleye, 2013). Informal alternative care which involves children been cared for by extended family members, family friends and community members has proven to provide children with continuity in personal relationships, socio-cultural environment and physical location (Chaitkin, et. al, 2017). This as noted by Chaitkin et al is because such arrangements have several advantages over formal placements, the first being that they are "owned" by the communities and societies concerned, having been developed in accordance with each one's socio-cultural norms and values. It has also been reported that children who are cared for in their communities are more likely to have high self-esteem, overall health, happiness and less sadness (University of British Colombia, 2010). Smyke, Zeanah, Fox, Nelson \&Anthire (2010) found that children placed in foster care which is a form of alternative care system before 24 months of birth were more likely to have secure attachments with their caregivers. In addition, children placed into foster care earlier showed more likelihood of being organized in their relationships with their caregivers.

Generally, literature on alternative care system for children in Nigeria differs. For instance Eseadi, Onwuasoanya, Ugwuanyi, Ugwu, \&Achagh, (2016) explored foster parents perception of the psychosocial need of foster children in Nsukka community of Enugu state. Nwokocha and Micheal (2015) explored factors influencing child fostering practice in Bayelsa state. Others have looked at sex preference and child labour in informal child fostering practices (Okunlola\&lkunmola, 2010; Tade\&Aderinto, 20I2). Few of the studies available explored reasons and prevalence of child fostering in Nigeria and further highlighted the various forms of abuse suffered by children in this fostering practice (Esedi et al, 20/5). While a few studies focused on knowledge and attitudes toward child adoption and fostering among infertile women in northern Nigeria (Abubakar, Lawan\& Yasi, 2013, Wusu, \&lsiugoAbanihe, 2006). Most of these studies identified poverty as the major reason for placement of children into alternative care system but most of the studies generally did not consider placement decision with regards to the interest of the child. This study therefore attempts to bridge the gap by exploring child vulnerability and placement decision in alternative care system in south east Nigeria. In view of this, the study tries to (a) explain reason for alternative care of children in Anambra, (b) find out who is involved in placement decision for children into alternative care and (c) explore the extent of child participation and best interest of children in alternative care system.

\section{Literature review}

Millions of children around the world are without, or at risk of losing parental care and face significant challenges in their daily lives which often have long term implication well into adulthood (Lee, 2010). A child's healthy development is best realized in a loving and caring family environment where an attachment and/or bond have been created and exist (Engle, Groaza, Groark, Greenber, Bunkers \&Muhamedrahimaor, 20II; Lee, Clarkson-Hendric\& Lee 2016). Removing children from their natural family environment by way of alternative care system either for formal or informal child fostering arrangement or placement into an institution should not be the bases for long term separation for a child and his/her family as this arrangement have been found to have negative effect on child development (Levin, Zeanah, Fox \& Nelson, 2014; Malinga\&Ntashwanga, 20II). Thus in order to prevent separation of children from their families, the United Nation on November 20, 2009, welcomed the Guidelines for the Alternative Care of children.

The Guidelines' for the Alternative Care of children outline the need for relevant policy and practice with respect to two basic principles. These are the principle of necessity and principle of appropriateness. Pichler and Ayoub (2010), explained that at the heart of necessity is the desire to support children to remain with, and be cared for by, their family. Removing any child from his/her family should be a measure of last resort, and before such decision is taken, a rigorous participatory assessment is required. Concerning appropriateness, the Guidelines defined a range of suitable alternative care options. Alternative care can take the form of informal care or formal care with respect to the environment where it is provided; alternative care can be in form of kinship care, foster care, other forms of family-based care placement, residential care, and supervised independent living arrangement for children (Roby, 201 I; United Nation Nations Guidelines on the Alternative Care of Children, 20I0).

Alternative care system for children is usually used interchangeable with foster care to refer to several approaches to child care practices in different countries across the globe. Foster care or child 
fostering refers to children living with and being cared for by adults other than their parents (Grant \&Yeatman, 20/4). Such care is usually outside the child's natural family environment. Children living outside their natural family environment in an alternative care setting which sometimes is referred to as kinship care or out-of-home placement either in a family-based environment or institutions are found throughout the world (Akresh, 2009; Eseadi, Achah, Ikechukwu-llomuanya, Ogbuabor, 2015; Isiugo-Abanihe, 1983, 1995; Julia \&Shailen, 20 I4; Kah, 2015; Kuniman, HamRijkc, Horksbergen\& Van Baar, 2013; Okunlola and Ikuomola, 2010; Stein, Hurlburt, Heneghan, Zhang, Rolls-Reutz, Landsverk, \& McCue -Horwitz, 20/4)). This care arrangement however thrives in various forms and nature in various part of the world.

Scholarly literature on alternative care system which is commonly referred to as child fostering in various regions in the African continent have under taken studies on the determinants, predictors and public perception of fostering arrangement in the different regions (Manderson\& Block, 2016; Schartz\&Seely, 2015; Hamphire, Porter, Agblorti, Robson, Munthail, Abane, 20I5). Several studies shows that socio-economic and demographic factors such as age, gender, level of education, marital status, occupation, income affects people perception on the reason for fostering in Africa (Ababeiribe\&Kyei, 201 I; Akresh, 2009, Issa\&Awoyemi, 2006; Nwokocha\&Micheal, 2015). Several studies also tend to show predictors of fostering in Africa. For instance it is found that unmarried and less educated mothers are more likely to foster their children than their married and more educated counterparts (IsiugoAbanihe, 1985). Akresh (2009) however found that the marital status of a network member influences the decision to foster-in a child. A network member in a stable marital union is more likely to receive a child compared to a divorcee, widow, or a member who has never been married. Mothers in household with other related kins are less likely to foster their children because alternative caregivers are available in the household (Bledsoe \&lsiugo-Abanihe, |98I). Isiugo-Abanihe (1985), Tade\&Aderointo, (2014) also found that fostering is more common among girls than boys. Rural families were also identified as being the supplies of foster children to urban families (Gibbison\& Paul, 2006; Odukoya, 2009). Kinship families such as uncles, grandparents' aunts, siblings, and cousins seem to be more preferred fostering pattern than with unrelated family members. Interestingly is the role of grandparents in formal and informal fostering of grand children. This role is clearly evident in literature as Schartz\&Seely (2015) noted that children born outside marriage are raised by grandparents.

Alternative care system of children in Nigeria takes the form of kinship care where children are integrated into extended family system and are being cared for by either uncles, aunts, cousin grandparents or other non-related family members (Folarin \& Dobson, 2015). There are however different types of alternative care system for children. For instance, some alternative care in Nigeria requires a child to live and learn from his master (Nwokocha\&Micheal, 2015; Odukoya, 2009)). This type of fostering is common with boys who are required to gain mastery in a particular skill before becoming independent. Before becoming independent, the child is expected to contribute to the income of the family by engaging in sales and other income generating activities for the fostered family (Nduka\&Duru, 20I4). Other kind of fostering requires the child to work as a paid domestic servant who is expected to perform various forms of domestic chores (Nkpoyen, 2012; Okafor, 2009; Okunlola\&lkunmola, 2010). This is common with girls who are required to baby-sit as well as engage in other domestic chores (Odukoya, 2009). Children are also in alternative care system for the reason of having access to schooling. Most parents in rural areas also fostered out their children with wellto-do relations in urban areas for the purpose of giving the child opportunity to acquire western education (Odukoya, 2009). Majority of these children however fall prey to traffickers, while other

\section{Theoretical framework}

The study is anchored on the Permanency Planning Perspective and the Family Preservation Model that promotes the best interest of the child and the natural parents (Glodstein, Freud \& Albert, 1976; Herfferman, Shuttleworth\&Ambrosino, 1997; Mass \&Engles, 1959; McGowan \&Mezan, 1983; Tracy, 1995). The Permanency Planning Perspective came into focus in 1959 as a result of the study on 'Children in Need of Parents' by Henry Mass and Richard Engler. The study which was considered a landmark study in the field of child welfare looked at foster care in nine representative communities in the United States (Popple\&Leighniger, 2002). The permanency planning perspective is a guiding principles in child protective services with the basic philosophy that every child has a right to grow up in a permanent, nurturing home. Such philosophical position dictates that services should be provided first to the child's family and that every attempt should be made to keep the child and the family together. Placement decision should also be in the best interest of the child. 
On the other hand, the Family Preservation Model was developed as a means of providing supportive services to child and families at risk in their homes and thus discouraging the option of going into alternative care. The model was based on the belief that if passionate support services are provided for a child in his/her home over a short-period of time even when it is so glaring that there is need to remove such child to a foster home, the provision of such support services will help prevent in the long run the option of placement into an alternative care system. The model is based on the assumption that the family is an important influence on children and that separation has detrimental effects on both parents and children.

\section{Method}

\section{Study area}

Anambra is highly urbanized state with $62 \%$ of its population living in urban areas (Anambra State Government, 2017). There are three senatorial districts in the state which are, Anambra North, Anambra Central and Anambra South. The study was carried out in Orumba North and Onitsha North which are two local government areas in Anambra South and Anambra Central senatorial districts respectively. The population figure of the state is 4.1 million with Orumba north local government area comprising of 172,773 and Onitsha north comprising of 125,918 (National Population Commission, 2006). The study population includes all children living in informal alternative care system in the state and all married persons (men and women) with children living in informal alternative care system with either related or unrelated family members. Divorced, separated, cohabiting and single parents were not involved in the study.

\section{Sampling procedure}

The sampling technique used in this research is multistage cluster sampling. According to Rubin and Babbie (2008) cluster sampling may be used when it's either impossible or impracticable to compile an exhaustive list of the element that composes the target population. It is often the case, however, that the population elements are already grouped into subpopulations and a list of those subpopulations either exist or can be created practically. To apply this, the state was first categorized into three zones based on the natural existing senatorial zones. Anambra state has three zones; Anambra North, Anambra Central, and Anambra South. From the three zones, two zones were purposively selected to ensure representation of rural and urban characteristic. This is enable the researcher observe how rural and urban dwellers view alternative child care system in terms of placement decision, reasons for placement and child participation. Anambra central was selected as the urban zone due to the presence of major urban centers, commercial activities and presence of social/economic institutions in the zone. The zone was also considered an urban area with the presence of the river Niger which is an important trading port. Anambra south was selected as the rural area due to the structural dimensions of occupations, ecology and socio-cultural element. At the second stage, the two selected zones where broken down into local government areas. Simple random sampling method by balloting was used to select one local government area each from the two selected zone. The selected local government areas are Orumba North Local Government and Onitsha North Local Government. Simple random sampling by balloting was again used in selecting one community each from the selected Local Government. From the selection, Ajali in Orumba North was chosen while Omoba Phase I was chosen from Onitsha North.

The study combined purposive and snowball sampling method in the selection of participant for the focus group discussion (FGD). The reason for using non-probability sampling method was to get people with the particular characteristics required for the study. The people with the required characteristic thus lead the researchers to more cases on the subject matter. The researchers made efforts to reach those who were disposed and willing to participate in the research.

Purposive and snowball sampling method were used in selecting 64 participants for the study comprising of 32 children in alternative care system aged I2-17 who are in Junior secondary school (JS I3 ) and 32 parents who are married and living with their partners. Children in alternative care system who participated in the study were children living with either related or unrelated family members. Such children must have lived in such home for at least one month. This in other words means the child must have spent at least one month outside his/her biological home. This age group was considered appropriate for the study based on the Nigeria Child Right Act 2003 that defines a child as any person below the age of 18years. Those considered as parents for the study are married men and women whose children are living with related or unrelated family member. Such parents are eligible to participate in the study if they have at least one child or more living in an alternative care system. The researchers are interested in knowing why married men and women place their children in alternative care system and what process is involved. 
Purposive sampling method was used in selecting two community secondary schools (one from the urban area and the other from the rural area) used for the study in both area.

\section{Data collection}

Eight focus group discussion (FGD) sessions were held in all, meaning that four FGD were held in Ajali and four FGD were also held in Omoba phase I. The FGD in each location was made up 8 male children in alternative care system, 8 female children in alternative care system, 8 married men and 8 married women. In the rural areas, discussion sessions were held under a mango tree in a selected community secondary school for children in alternative care system and a community hall for married men and women. This was based on what was available and convenient. In the urban area, the sessions were held in a small church building for married men and women and a secondary school hall for children in alternative care system. Choice of venue was depending on what was available and convenient in each location. The adults involved in the study gave oral consent and participated willingly having been informed of the aims of the research. The children in the research were not forced to participate in the study, as the researchers sought the permission of the foster parents through the teacher in the school a week before the focus group discussion. Oral permission was sought from the teachers who insisted on knowing the objective of the study and the questions the students are meant to answer. This according to them was to enable them pass appropriate information to the foster parents. This was granted by the researcher. Based on their permission, the discussions were recorded with a recording device, while a note-taker took notes. Research assistants who are from similar cultural backgrounds with the participants were trained for 2 days on how to conduct FGD. Additional prompts based on the response of the respondent were used to elicit information as the discussion was going on. The respondents were also required to provide some demographic information. The discussions were conducted in lgbo languages. The research instrument was developed by the researchers and pretested using an FGD session in another Local Government Area of the state to ensure its reliability.

\section{Data analysis}

In analyzing the qualitative process, the process began with careful recording, editing and transcribing of the raw data into English language. The raw data was in the local dialect and so needed to be transcribed into English language. The transcription was done by the research assistants who were indigenes of the state under study and so understands and speaks the local dialects fluently. The transcripts they generated from each of the FGD in the two locations were read for content by two of the research assistant. The transcribed discussions were compared to the recorded discussions by the researchers to ensure that original meaning of what participants said was retained. Themes were developed after series of modifications of research questions courtesy of field experiences (Babbie, 20I0). The final themes became (a) views on reasons for alternative care system, (b) cultural benefits of alternative care systems, (c) placement decision in alternative care systems, (d) child participation and best interest of the child in alternative care system,

\section{Result}

The result on the findings of the study will be discussed in two sections. Section A will focus on the views from Adult participants who are married men and women, while section $B$ will focus on the view of children in alternative care system. Reason for this is for more clarity in the presentation of the findings of the study

\section{Section A}

\section{Demographic characteristic of participants}

The parents that participated in the study were of the Igbo tribe. Age of the participant ranged from 31 to 72 year. Those that fall within the age bracket of 31 45 constitute the younger age forming about $45 \%$ of the participants while about $55 \%$ of the participants fall within the age bracket of 46 and above and classified as the older age. The entire participants are married and have at least one child living in an alternative care setting either with related or unrelated family member. Majority of the participant have 4-6 children in their household that are not living in alternative care. Farming and trading was identified by the participant in both rural and urban area as the major occupation they engage with the exception of one elderly women in the urban area who was proud enough to identify herself as a retired headmistress from a community primary school. The participants have various levels of educational qualification ranging from Standard 6, Teacher Grade II Certificates, First School Leaving Certificate (FSLC), West Africa Examination Certificate and Ordinary National Diploma (OND).

\section{Participants views on reasons for alternative care system in south eastern Nigeria}

Participants' views on reasons for alternative care system in south east Nigeria which was one of the themes developed for the study reveals that majority of parent at both the urban and rural area agreed that

http://aps.journals.ac.az 
poverty was the main reason why they send their children to alternative care system. The response of a female participant from the rural areas was captured with the statement "ah my sister, if I should take care of all the children that I have, am sure by now I will not be alive. I don't have work, no money so how do you think I can train these children". Another male participant from an urban area describe the government as not responsive in addressing the plight of poor families hence the need to look for alternative means of taking care of children by way of foster care. He said "three of my children are living with my relation here in Onitsha. I can't care for them because I am just a farmer and what I cultivate is just to eat and be alive'. Majority of the participant at both the rural and urban agreed that the farm output from their subsistence agriculture cannot take care of the vast need of the family. They also agreed that if the government is funding farmers, they can engage in mechanized agriculture which will help them produce more thereby providing opportunity to care for their family. While poverty was seen as a major reason for sending children to foster homes, some of the participants pointed out that the desire to give their children opportunity to acquire western education was their reason for choosing alternative care. Interestingly, this reason was held by majority of the female participant from the rural area. A female participant was of the view that "since I did not have the opportunity of going to school because my parents were poor, I don't want my children to experience the same thing. My children are living with some family friends and I am happy they are all going to school". One remarkable thing that emerged during the focus group discussion in both rural and urban area was that most female participants preferred their children going to school than learning a trade. On the other hand, majority of male participants in the urban areas and just a few from the rural area see skill acquisition as the reason for allowing their children go into alternative care. A male participants from the rural areas felt that acquiring a skill is better than western education. This male participant angrily said "Those that went to school to read all kind of things are they not the ones going up and down looking for work? Infact some of them end up learning different skills just to survive. For me oh! I still will prefer our children learning different skill while living with people than going to school and wasting time". He concludes by saying that there is an igbo adage that said 'Kwoommirimgbeodinaobeokpa' meaning make hay while the sun shines. Some of the participants believe that children should be trained early in life to embrace hard work so as to develop resilient skill. A retired headmistress from an urban area and two male participants from the urban area emphatically said that their reason for sending their children to alternative care home was for the children to experience life and living outside their natural family environment. As presented by the headmistress she said"children must learn from other people when they are growing up. If I keep all my children in my house then, I am not helping them. How much was I receiving then as a grade II teacher..There is something about life they may not know that others will teach them. What I know as a teacher is because somebody taught me when I left the comfort of my house". One religious man from the rural area who kept on projecting his religious ideologies said 'I have money and can take very good care of my children but I still send some of them to go and live with people. My main reason is for them to fear God and be hardworking. They are living with a priest who is from my community'

\section{Cultural benefits of alternative care system in south east Nigeria}

On cultural benefits of alternative care system which was one of the themes that came up during the discussions which was not originally part of the questions in the FGD guide developed by the research, various views were held by the participants. One remarkable things about the various view was that majority of the participants believe that alternative care system is culturally acceptable means of training children. This view was strongly held by both female and male participants. A female participant from an urban area said: "child fostering is a tradition that was handed over to us by our great grand fathers. We were told that in those days, children live with extended family members and sometimes some can even go far away to live with relations who are elderly... this was to help the child learn the tradition of their ancestor". Another male participant from an urban area said that "'child fostering is a cherished practice that parents aspire for their children". This same view was held by a male participant in the rural area who said that "child fostering is well known in the lgbo tradition because children are the elders of tomorrow... before a child will become an elder, he/she must live with an elder and that elder may not necessarily be the biological father or mother of a child." Another male participant from the rural setting noted that "..our culture in Igbo land strongly support child fostering. Igbo people are strong people and that is because of the kind of training given to them from childhood... for a child to succeed in life, it is expected that the child must learn from other people. Sometimes the training is difficult and demanding but that is what will make that child to come out a better person". He 
ended by saying " go and ask the blacksmith how he produces gold"? Maintaining close kinship ties was also identified as a very important cultural benefit of alternative care system. Participants in both urban and rural areas explained that children are fostered to enable family members maintain strong kinship ties. Participants from both urban and rural areas identified that even though cultural values are being daily eroded with foreign values, child fostering still remains a very strong means of maintaining kinship ties. A female participant from a rural area said that: ... "children live with extended family members so that they will not forget their root. We have all left the village to the city and don't even know where some of us are living but we use child fostering to connect our families. When children live with their family members, they know who is who to avoid them marrying themselves in the future which is a taboo in lgbo land. My children spend their holiday with my extended families in different parts of the country. To me this is child fostering and it helps children to know their relations".

Another female participant from a rural area said that "a child that does not visit his paternal and maternal family occasionally will not know his root. A child needs to spend some time living with the other extended family member and even unrelated family members. This is because as a parent, there are some things that I may not be able to explain to my child. The child living with other family members will bring some new experiences and lesson for the child to learn and our tradition supports these" Some of the participants objected to children living with unrelated family members as they felt that the children are bound to lose their root and kinship tie

\section{Placement decisions into alternative care system arrangement}

Placement decision into alternative care system arrangement was one of the questions originally in the FGD guide that was not modified during the discussions. Majority of the participants from both urban and rural areas mentioned those that were instrumental in the placement decision of their children into alternative care. Notable among such was the involvement of family members usually extended family members; very close friends, church members, religious leaders, social welfare officer, and neighbours. Participants from both urban and rural area did not support the idea of involving the social welfare department during placement decisions. Majority of the decision to place children into alternative care system was done by parents themselves and some extended family members from the paternal and maternal side. A male participant from the rural area said "I made the decision myself after I discussed with my wife and my brother. We want the best for the child so we sent him to Kano to live with my wife's brother who is working in a leather company". Another male participant from an urban area said "before I took that decision which was hard for me I called my elder sister and one of my kinsmen who is very close to me. The three of us took the decision and I am happy that I took that decision that day'. The boy is doing very well". The role of religious leader and family friends was also noted in the placement decision into alternative care. A female participant in the rural area noted that "it was my friend in the church that helped us when we wanted one of our children to learn a skill. My friend told me that his brother wants a boy that he will train in car importation. I discussed with my husband and he agreed. It was my friend that took the child to Port-Harcourt". Another male participant from the rural area said it was a social welfare officer that helped in the placement decision. According to his submission he said: ... I have two children in a motherless baby's home. They are twins and were taken there when my wife died three years ago and nobody was willing to help me.. The other children at home want the twins to be with us but I said no. This is because I don't know how am going to take care of them. Since the church is feeding them and paying their school fees why should I worry myself? Let me take of the ones with me for me, when the church return the children to me, I will know how to manage myself... no marriage. Majority of the participants from both urban and rural areas did not subscribe to involving the social welfare department during placement decision for their children into alternative care system. One of the male participant from the rural area said, 'this is our tradition so why must we bring government into it. Government has their own rules and we also have our own rules and customs". So let government manage their problem while we also take care of our own". Another male participant from the rural area said, "there is no need bringing social welfare into this matter because am sure that social welfare will even create more problem for us. We still engage in family meetings in the village and we know who is who. We know those that can take good care of our children for us". This was supported by majority of participants from the rural area.

\section{Child participation and best interest of a child in alternative care arrangement}

Findings from the study shows that children are often not involved during placement decisions as their views are considered not necessary. Decisions are taken in their best interest as most parents believe that they are too young to know what is good for them. This was captured when one of the male 
participants from the urban said, "I want the best for my children, and they may not know this. I am their father and I will not deceive them. Sending them to live with people is good for them and for me also. If I ask for their opinion, what will they say, tell me? If they say they will not live with the person I want them to live with, who is going to help me train them? So they must go. My son is doing well in his business with his masters. I use to visit them" Parents often assume that they are protecting their children when they take major decision about their welfare without involving the child. Findings from the study reveal that children are mainly observers in events that have to do with their welfare. A male participant in the rural area was of the view that: "Suffering is part of life, I also suffered and even still suffering. I don't want my children to continue the suffering. To stop the suffering, they have to go out and live with people who have money so that they can train them in learning a good trade. God gave me children so that I can direct and show them the good way not the children telling me what I should do or even directing us. I know that in the future they will understand the good I have done for them but now they will not understand. I have six children and am a bus driver, how much do I come home with every day? The money is just to cook soup and do small small thing in the family. Two of my boys are learning trade and one girl is helping to carry baby for my sister and she is going to school. I am happy that at least somebody can help me in raising my children. From the discussion, it was clear that most participants' feels placement into foster care is in the best interest of the child because of the need of the moment such as need to acquire western education, learn a trade and as an investment for the future. A male participant from an urban area explained that "every decision that a parent is making for his child or children is the best thing that can happen to the child". Majority of male participants from the rural areas agreed that children are responsibility given to by God to parents and that they must give account of on how they were able to contribute to their growth and development. This was captured when some of them said, "raising our children with our family members is not a bad thing. Once there is an agreement between the families, the child will go and stay with them". Placement into alternative care system therefore was the best they can do for a child especially when family survival is under treat. A female participant from the rural area feels it is not appropriate to involve children in such decision making because according to her " it is true that some children will not want to live with foster parents but we must encourage them to go because we cannot do everything for them. if we start asking them will you go or will you not go, they may not have respect for us as parents. That then means that we will start taking permission from our children". Yet another female participants from the urban area said "there is nothing bad with talking with the child and allowing he/she to decide whether to live with foster parents or not. We even did it in my family when one of our daughters was to live with a family member at Awuchi in Edo state. My fear is that if we start doing this, are we not giving so much power to the children to disrespect us as parents? This view as expressed above by the female participant from the urban area was supported by most participants from that area.

\section{Section B}

\section{Socio-demographic characteristic of participants (Children)}

The children that participated in the study were of the lgbo tribe from the south east geopolitical zone except 6 children ( 4 female and 2 male) in alternative care system that were from the north-central and south-south geopolitical region of Nigeria. These groups of children though from a different geopolitical zone were fluent with the lgbo language having spent over five years in alternative care with unrelated family members. For this reason, there was no need for an interpreter. All the children that participated in the study were in Junior secondary school. The ages of children in alternative care setting were categorized into younger age and older age. Those that fall within the age bracket of younger age were children from 12-14 years while those that were categorized as older age were children that fall within the age bracket of $15-17$ years. About $60 \%$ are older children whereas younger children just constitute $40 \%$. Majority of the participant have minimum of primary education. About $85 \%$ of the participants have spent over 6 years living with their foster parent without any form of contact with their biological parents and no plans of reunification in view, while $15 \%$ have regular contact with their biological parents but have no idea if there are plans of reunification in the future.

\section{Participants views on reasons for alternative care system in south eastern Nigeria}

Majority of children from both the urban and rural areas do not know the reason why their parent sent them to alternative care home. While some of the children think that they are in alternative care because they have lost one or both parents, other felt that they are in alternative care because of the need to help with house chores and babysit for their relations. Some were excited that they have the opportunity of going to school in their new home and 
thus felt that was the reason of the alternative care. A few of them however pointed out reason for their living in alternative homes based on the little understanding they have. For instance a female child from an urban area said 'my parent don't have money and so they say we should live with people so that those people will help to train us' One of the male participant from the south-south geopolitical zone who spoke in pidgin English said 'my father and mother don die and my father's brother say make I go stay with one man who dey come to our church wey the children dey Onitsha. I dey go school for morning and I dey learn printing work for evening. A little girl who was 12 years old and from the rural area said "my grandmother said that I will go to school if I help my mothers' sisters to carry her baby. I am carrying the baby but I go to school only two times in the week".

\section{Placement decision into alternative care system arrangement}

Some of the children know little or nothing on why they were moved from their biological home to another home. Majority could not say precisely who took the decision. Some were however able to recollect those present during the decision making process as captured in the feedback below from a male participant from an urban area. "I don't know why my parents say I should live with my uncle. My father and my mother's brother told me I will be going to live with somebody in Onitsha, I don't know the person and the person does not know me. My father told me that I will learn how to sell market and make money so I can help them in the village. I go to school in the morning and then go to shop after school. I am happy living with my oga (oga means master)but I will like to go back to my village so I can see my parents and friends". Most of the foster children that participated in the FGD admitted that they were not consulted during the placement decision. A female participant said: Some people came to our house and after some days my mother told me I will be going to live with my father's relations in Onitsha. Nobody told me why I will be going to live in Onitsha but I know that some of my friends in the village that have gone to Lagos are living with people. Some are doing work and some are carrying babies. I was not happy because I will miss my brothers and sister. We are seven in our family plus me is eight. I have been living here for since, for a long long time. I have carried three babies. I am happy that I am going to school. In my village I don't go school.

\section{Discussion}

Finding from this study reveals that most placement decisions into alternative care system are done by parents, friends and members of the extended family system. This was noted when a participant said that "before I took that decision which was hard for me I called my elder sister and one of my kinsmen who is very close to me. The three of us took the decision and I am happy that I took that decision that day'. The boy is doing very well". This thus implies that the age long tradition and commonly held belief in traditional Nigerian Society that, 'A child does not only belong to his/her biological parents but rather belongs to the immediate and the whole extended family' still stands (Ekpe\&Mamah, 1997; Oni, 1995). This was in agreement with the view held by Djettaii and Maryrand (20II) that in many African societies, kinship care is an accepted means of raising children. According to the researchers, for a broad range of reasons children are looked after on an ongoing or indefinite basis by relatives, friends or others. Otite and Ogionwo (2006) noted that children are cared for by not just the biological parents but also other significant members of the extended family. This view was also upheld by Olusegun \&Benard (2013) as they explained that childrearing practices in Nigeria are common within the extended family system or lineage, and the costs of raising children are not borne solely by the biological parents. Very close relatives also share the costs of raising children, in terms of emotion, time, finance and other material support, since all children together comprise the strength of the lineage.

The involvement of social workers and the social welfare agency as regards placement into foster homes is still very minimal looking at the findings from the study. Majority of the participants from both urban and rural areas did not subscribe to involving the social welfare department during placement decision for their children into alternative care system. One of the male participant from the rural area said, 'this is our tradition so why must we bring government into it. Government has their own rules and we also have our own rules and customs". So let government manage their problem while we also take care of our own". Another male participant from the rural area said, "there is no need bringing social welfare into this matter because am sure that social welfare will even create more problem for us. We still engage in family meetings in the village and we know who is who. We know those that can take good care of our children for us". This was supported by majority of participants from the rural area.

Findings from this study also reveal that parent make placement decision for their children for reasons such as need to acquire western education 
and to learn a skill which is a way of offering children alternatives opportunity to better their lots. Similar results have been recorded in other scholarly articles (Akresh, 2007; Akresh, 2009; Zimmerman, 2003). One remarkable finding from the current study was on the views held by majority of the participants on 'cultural benefit of alternative care system'. Many strongly believed that it is culturally acceptable means of training children. Parents in the FGD see alternative care as a cultural acceptable way of training children and preparing them for adult role in the society. They all agreed that children who live with foster families are better prepared for adult life and are more resilient than those that spent their entire life with their biological parents.

For a broad range of reasons children are looked after on an ongoing or indefinite basis by relatives, friends or others. Parents often assume that they are protecting their children when they take major decision about their welfare without involving the child. Findings from the present study reveal that children are mainly observers in events that have to do with their welfare. The psychological aspect of living in a new environment for a child without adequate preparation seems to be missing entirely when parents make placement decision for children. The question is still in whose best interest is such placement decision? Is it in the best interest of the child or the best interest of the parents and extended family? Any alternative care for a child should be in the best interest of the child to allow the child adjust properly in the new environment and make good use of the opportunities provided in the new home.

\section{Conclusion}

Findings reveal that many parents still believe that there is no need going through social welfare agencies during placement of children into alternative care system. There is also the belief that children should not be consulted when decisions are taken on their behalf. This according to some participants during the focus group discussion is to avoid empowering children to disrespect adult. This shows that participants may not be aware of the fundamental principles in the Child Rights Act 2003 which stipulate that everything that concerns a child must be done in the "best interest' of that child. The implication for this is that social workers need to develop various enlightenment programmes using the print and electronic media to educate the public especially children in alternative care, biological parents and foster parent on the importance of the Child Rights Act.

\section{Limitations}

Certain limitations inherent in this study should be noted. This study is based on a limited sample of 64 participants. This means that some groups of children living in alternative care system and even parents whose children are in alternative care system have been excluded from the study. Limited by sample size, this study cannot generalize about the best interest of the child in alternative care placement in the state. However, the finding will add to the existing body of knowledge in the area. With a higher sample size, finding may yield more varied result. In summary, this study demonstrate that informal child fostering as an alternative care system for vulnerable children still thrives in southeastern Nigeria with majority of parents engaging in placement decision in what they consider to be in the best interest of the child. This study opens a door for further studies on the best interest of the children in placement decision on alternative care system in Nigeria.

\section{References}

Abeberese, A. and Kyei, P. (20II) Status of West Africa's fostered children online. Paper Presented at Six African Population Conference, Burkina Faso. 5-9 Dec.

Abubakar, S Lawan,U. M \& Yasi J. N (20I3) Knowledge and attitudes toward child adoption and fostering among infertile women in northern Nigeria. Sahel Medical Journal, 16 (I), 19-23

Akreh, R. (2009). Flexibility of household structure: Child fostering decisions in Burkina Faso, Journal of Human Resources, 44(4), 976-997.

Akresh, R. (2003). Risk, network quality \& family structure: Child fostering decision in Burkina Faso. Retrieved from http://www.econ.yaleedu/seminars/trade/tdwoz/a kresh-03968.pdf.

Anambra Stat Government (20I7). History of Anambra State. Retrieved from file://C:/Users/hp/Documents/population\%20of \%20anambra.htm

Asuma, D. Boakye-yiadom, L \&Owo (2018). Understanding why household foster children: evidence from Ghana, African social science Review, 9(I), 52-65. Available at: http://www.bettercarenetwork.org/docs/Guidelin es-English.pdf

Babbie, E. (20I0). The practice of social research (I2th ed.). Belmont, CA: Wadsworth Cengage Learning.

Bledsoe C, Isiugo-Abanihe U. Strategies of childfosterage among Mende grannies in Sierra Leone. In: Lesthaeghe RJ, editor. Reproduction and Social 
Organization in sub-Saharan Africa. Berkley, CA: University of California Press; 1989. pp. 443-475.

Boothby, N., Balster, R.L., \&Goldman P, (2012) Coordinated and evidence-based policy and practice for protecting children outside of family care. Child Abuse Neglect, 36(7), 43-5I.

Chaitkin, S., Cantwell, N., Gale, C., Milligan, I., Flagothier, C., O'Kane, C., Connelly, G. (2017) Towards the right care for children : Orientations for reforming alternative care systems - Africa, Asia, Latin America. [Report] , http://dx.doi.org//0.284I/069502

Djebbari, H. \&Mayrand, H. (20I I). Cash transfers and children's living arrangement in South Africa

Egwemi, V. \&Odo, L.U. (20|3). Rural development and poverty eradication in Nigeria. JORIND, II (I), I0I-I07

Ekpe, C.P. \&Mamah, S.C. (1997). Social work in Nigeria: A colonial heritage, Enugu: UNIX Oriental Press.

Elegbeleye, A.O (2013). evaluation of support facilities for institutionalized orphans in Nigeria. International Journal of Current Research, 5 (5), 1049-1053,

Eseadi, C., Onwuasoanya, P. N., Ugwuanyi, R.A., Ugwu, E. C., \&Achagh, W (20I6). Foster parents perception of psychosocial needs of children in foster homes: Evidence from an urban town in Nigeria. International Journal of Interdisciplinary Research, 3(I), I0-I2

Eseadi, C.,Achagh,W., Ikechukwu-llomuanya,A. B \&Oguabor, S. E.(20I5). Prevalence of baby factory in Nigeria: An emergent form of child abuse, trafficking and molestation of women. Nigeria. International Journal of Interdisciplinary Research $3(1), 1-12$

Engle, P.L, Groza V. K, Groark, E. J, Greenberg, A, Bunkers K, M. \&Muhamedrahimov R.J (20II). Children without permanent parents: Research, practice and policy. Child Development 76(4) 190-222

Folarin, A., \& Dobson, R. (2015). Assessment report of the alternative care system for children in Nigeria. Lagos: SOS Children's Villages Nigeria

Gaydosh, L (2015). Childhood risk of parental absence in Tanzania. Demography 52(4), II2III 46

Green, Z. (20|5). Global economy, poverty and social inequality. Retrieved from: https://www.globalresearch.ca/one-and-a-halfbillion-people-live-on-less-than-I-25-perday/5443472

Goldstein, J., Freud, A. \& Albert, J. ( 1973). Beyound the best interest of the child. New York: Free press.
Grant, M.J. \&Yeatman S.( 20I2). The relationship between orphanhood and child fostering in subSaharan Africa, 1990s-2000s. Population Studies, 66, 279-295.

Hefferman, J., Shuttleworth, G., \&Ambrosino, R.. (1997). Social work and social welfare: An introduction (3rd. ed,). New York: West Publishers.

Heymann J, Sherr L, Kidman R. (20/2). Protecting childhood in the AIDS Pandemic: Finding solutions that work. Oxford. Oxford University Press.

Isiugo-Abanihe, U.C. (1983). Child fostering in West Africa: Prevailing determinants and demographic consequence. Health Transition Review, 5, 2I-34.

Isiugo-Abanihe, U.C. (1985). Child fosterage in West Africa. Population and Development Review, II (I), 53-74.

Issa, F. Y. \& A.O. Awoyemi, (2006) 'Child fostering and adoption in Nigeria: A case study of Kwara State and literature review', The Tropical Journal of Health Science, I3(2): I- I 2

Jones, N., Presler-Marshall, E., Cooke, N. and Akinrimisi, B. (20/2) Promoting synergies between child protection and social protection in Nigeria'. ODI/UNICEF Nigeria

Julie, S., \&Shailen, N. (20/4). Kinship care in UK: using census data to estimate the extent of formal and informal care by relatives. Child and Family Social Work, 19, 44-54

Kah, H. K (20I5) From foster care to enslavement: What future for African social security system. Mordern Africa Politics, History, 2(2),75-I02

Kunimah, S., HamRijk C., Hoksbergen, R.A. A \& Van Baar, A. L (20I3). Children without parental care in Poland: Foster care, institutionalization and adoption. International social work, 0(0), I- 16

Lawson, D.W., Schaffnit, S.B., Hassan A., Ngadaya E., Ngowi B., Mfinanga S.G.M., James, S.,

\&Borgerhoff Mulder M. (2017) Father Absence but Not Fosterage Predicts Food Insecurity,

Relative Poverty, and Poor Child Health in Northern Tanzania American Journal of Human Biology, 29, e22938

Lachand, D., LeGarand, T.A \&Kobiane (20I6). Child fostering and children's human capital in Quangadougoh (2016). Population Review 55(I).27-48

Lee, E., Clarkson-Hendrix \& Lee, Y. (2016). Parenting stress of grandparents and other kin as informal kinship caregivers: A mixed methods study. Children and Youth Services Review, 69, 29-38

Levin, A., Zeanah, C., Fox, N. \& Nelson, C. (20I4). Motor Outcomes in Children Exposed to Early Psychosocial Deprivation. The Journal of Pediatrics, 164, (I), I23- I30, 
Malinga T, \&Ntshwarang PN. (20I I). Alternative care for children in Botswana: a reality or idealism? Social Work and Society 9: 1-13.

Manderson, L. \& Block, E. (2016) Relatedness and care in Southern Africa and beyond. Social Dynamics, 42(2), 205-2। 7

Mass, H. S. \&Engler Jr, R. E. (1959). Children in need of parent. New York: Colombia University press

McGowan, B. G \&Meezan, W. (1983). Child welfare: Current dilemmas and future direction. Ilinois: Peacocck publishers

Nduka, I.\&Duru, C.O.(20l4) The menace of street hawking in Aba metroplolis, South- East Nigeria. Journal of Medicine, Medical Scinences, 5(6), I33140

Nwokocha, E. E \&Micheal, T.O (2015). Factors influencing child fostering practice in Bayelsa state Nigeria: Danling between necessity and reciprocity. The Nigeria Journal of Sociology and Anthropology, 13(2),

Odukoya, A. (2009) Child labour in Nigeria: Historical perspective.' In H. Hindman, ed., The World of Child Labour: A Historical and Regional Survey. Armonk, NY: M.E. Sharpe Inc.

Okafor, E.E. and Amayo, O.E. (2006) Parents and their coping strategies in Nigeria: A study of selected working mothers.' International Journal of Sociology of the Family 32(I): 87- III.

Okafor, E.E. (2009) The use of adolescents as domestic servants in Ibadan, Nigeria.' Journal of Adolescent Research 24(2): 169-193.

Okunmola, A \&lkunmola A. D (2010) Child labour in fostering practice: A study of Surulere local government Area of Lagos, Nigeria. The Social Science, 5 (6), 493-506

Olusegun, A.J. \&Benard, O. (20/3). Socialization and child rearing practices among Nigerian ethnic groups. Academic Journal of Interdisciplinary Studies, 2(2), 249-256

Oni, J.B. (1995). Foster children's perception of their health care and illness treatment in Ekiti Yoruba households, Nigeria. Health Transition Review, 5, 2I-34.

Pichler, R. ,\&Ayoub, J. (20I0) Guideline for the Alternative Care of Children: A United Nations Framework. Innsbruck-Austria: SOS Children's Villages International Programme Development.

Roby, J (20II) Children in Informal Alternative Care. Discussion paper. UNICEF, New York. Retrieved on January 10, from: http://www.bettercarenetwork.org/BCN/details.a sp?id $=25477 \&$ themelD $=1002 \&$ topiclD $=1013$

Popple, P. R \&Leighninger, L.(2002). Social work and social welfare and American society. London: Allyn\& Bacon
Schartz E. \& Seeley I (2015). Gender, aging and casework in East and Southern African: A review. Glob Public Health I0(I0), I I 85- I 200

Stein, R. K., Hurlburt, M. S., Heneghan, A. M., Zhang, J., Rolls-Reutz, J., Landsverk, J., \& McCue Horwitz, S. (2014). Health status and type of outof-home placement: Informal kinship care in an investigated sample. Academic Pediatrics, 14(6), 559-564.

Smyke, A. T., Zeanah, C. H., Fox, N. A., Nelson, C. A., \& Guthrie, D (20I0).Placement in foster care enhances quality of attachment among young institutionalized children. Child Development, 8I (I), 2I 2-223

Tracy, E. M.(1995). Family preservation and home based services in Richard, L Edward and June GrayHoppsedsEncyclopeidia of social work 19th ed Washington DC, NASW, 20-2I

Tshoose C. (20I0). The impact of HIV/AIDS regarding informal social security: issues and perspectives from a South African context. PER: Potchefstroom Electronic Law Journal 13, 408447.

UNDP (2015) 2030 agenda for sustainable development goal. Retrieved from www.ng.undp.org/content/nigeria/en/home/post20I5/sdg-overview.html

UNICEF (20I7). Data gaps on children in residential care leave the most vulnerable unaccounted for.

Retrived

from

file:///C:/Users/hp/Documents/alternatives\%20to

\%20formal\%20child\%20fostering\%20statistic\%2 Ounicef.html

United Nations Guidelines for the Alternative Care of Children (2010): resolution adopted by the General Assembly, 24 February 2010, (A/RES/64//42). Retrieved on January 17, 2018

University of British Columbia (September 14, 2010). Children's happiness linked to supportive environment outside the home: UBC Study. Retrieved fromhttp://www.publicaffairs.ubc.ca/2010/09/14/c hildren'shappiness-linked-to-supportiveenvironment-outside-the-homeubc-

Washington, T., Gleeson, J. P., \&Rulison, K. L. (20I3). Competence and African American children in informal kinship care: The role of family. Children and Youth Services Review, 35(9), I 305-I 3 I 2.

Williamson, J, \& Greenberg, A. (20I0). Families, not orphanages. (Better Care Network, working paper). Retrieved on November, 2017 from http://www.bettercarenetwork.org/docs/Families \%20Not\%20Orphanages.pdf;

World's Vulnerable Children (2010). United States Government: Fifth annual report to Congress on 
PL 109-95. Retrievable at:

http://pdf.usaid.gov/pdf_docs/PDACU307.pdf

Zimmerman, F. J. (2003). Cinderella goes to school: The effects of child fostering on school enrolment in South Africa. Journal of Human Resources, 38 (3), 557- 590. 